\title{
SUSCEPTIBILITY OF CERTAIN TOMATO CULTIVARS TO INFESTATION WITH TUTA ABSOLUTA (MEYRICK) (LEPIDOPTERA:GELECHIIDAE) IN RELATION TO LEAFLET TRICHOMES
}

DARBAIN, SALEM ${ }^{1}$; AZZA K. EMAM ${ }^{2}$; A. HELMI²;

S. S. EL- BADAWY ${ }^{1}$ and S. MOUSSA ${ }^{1}$

1. Plant Protection Research Institute - Agricultural Research Center, Dokki, Giza, Egypt.

2. Department of Plant Protection, Faculty of Agriculture, Ain Shams University, Cairo, Egypt.

(Manuscript received 1 September 2016)

\begin{abstract}
$\mathrm{T}$ he tomato leaf miner; Tuta absoluta (Meyrick) is one of the most important pests of tomato all over the world. Choosing of tomato cultivar plays an important role in controlling this insect pest. The susceptibility of some tomato cultivars to infestation with this pest in relation to leaflet trichomes was studied. Five tomato cultivars; Alissa F1, Super strain B, G.S 12 F1, E603 F1(Logain) and Indos were planted in both early summer and summer plantations. Results indicated that the most susceptible cultivars to the infestation were Alissa F1 and Super strain B while Logain cultivars was the least susceptible one. Two trichome types were detected in all tomato cultivars leaflet; one of them is glandular and the other is non glandular. Glandular trichomes length and density showed high significant negative correlation with $T$. absoluta infestation and length of normal trichomes showed significant negative correlation. So it is suggested that density of glandular trichomes might plays an important role in tomato cultivars susceptibilities.

Key words: Tomato borer, Tuta absoluta, Susceptibility, Trichomes, Seasonal abundance, Cultivars, Egypt.
\end{abstract}

\section{INTRODUCTION}

Tomatoes, Lycopersicon esculentum Mill. are one of the most important vegetable crops around the world and they are also the most popular garden vegetable and commercially in 159 countries. There are more than 700 varieties of tomatoes all over the world. The major producers of tomatoes in 2009 were China, the United States, India, Turkey, Egypt, Italy and Iran. According to the last estimates from the Egyptian Ministry of Agriculture and Land Reclamation in 2013, the tomato production increased to 16,636 tons/feddan with a total yield of $8,571,050$ tons from a total area of 515,225 feddan (Anonymous 2013; FAOSTAT 2014). Tomato borer, Tuta absoluta (Meyrick) (Lepidoptera: Gelechiidae) is one of the most important pests of tomato. Larvae are the most damaging stage, which stay from 12 to 15 days. This 
pest invaded Egypt in 2009. It is a pest with high damage potential. It has 10-12 generations per year. Females lay approximately 250 eggs. Tomato plants can be attacked at any developmental stage, from seedlings to mature plants. T. absoluta causes yield losses up to $100 \%$. The highest population of $T$. absoluta occurred between April - Jun. and September - October. in Italy. Viability of T. absoluta larvae was $36.6,45.1$ and $65.4 \%$ when fed on tomato plant stages (before flowering, before developing fruits and after developed fruits, respectively)(EPPO, 2005; Torres et al., 2001; Nannini et al., 2011; Roditakis and Seraphides, 2011; Temerak, 2011; Khanjani, 2013).

Trichomes are epidermal protuberances that have distinguishing height/width ratios. Trichomes can be single-cell or multicellular, but the criterion that is mostly used to classify them is whether they are glandular or not. The presence of trichomes and their exudates have an inhibitory effect on the insect oviposition. In genus Lycopersicon different metabolites are secreted by leaves and stems glandular trichomes. (Behnke, 1984; Werker et al, 2000; Gilardon et al., 2001). Leite et al. (2001) found a significant negative relationship between egg and larva density and type of non-glandular trichomes on leaf vein and caused a negative effect on individual moth population fitness like egg deposition and larva feeding. Glandular trichomes are known to secrete a variety of secondary metabolites that are able to physically entangle insects. (Williams et al., 1980; Kennedy and Dimock, 1983; Weston et al., 1989; Eigenbrode and Trumble, 1993; Simmons et al., 2003).

This study aimed to determine the susceptibility of different tomato cultivars to infestation with Tuta absoluta and the relation of leaflet Trichomes to these susceptibilities.

\section{MATERIALS AND METHODS}

\section{Experimental Area and Design:}

To detect the susceptibility of certain tomato cultivars to infestation with T. absoluta, five tomato cultivars; Alissa F1, Super strain B, G.S 12 F1, E603 F1(Logain) and Indos were cultivated in 15 equal plots (three replicates of each cultivar) in complete randomized block design at Qaha region (Qalyubiya Governorate) during early and late summer plantations throughout two successive seasons; 2013 and 2014. Early summer plantation date was on the first February and seedlings were transplanted to the open field in the end of Feb. Summer plantation date was in mid June and seedlings were transplanted to the open field in mid July. All usual 
agricultural practices were applied and the whole experimental chemical control measures were entirely avoided during the studied duration.

\section{Sampling procedures:}

Sampling started after one week of seedlings transportation and continued weekly until the end of each growing season throughout both successive seasons. Direct counting of $T$. absoluta larvae on thirty leaflets of each cultivar (10 leaflet * 3 replicates) was conducted.

\section{Scanning of Leaflet Surface Features:}

For estimating different leaflet surface trichomes type and density, five young tomato leaflets were chosen from each cultivar for using the Analytical a Scanning Electron Microscopic Technique (SEM) (Joel jsm.6390LA) at the Central Laboratory of Water Station Fustat, Greater Cairo Water Company.

Samples were washed in $0.1 \mathrm{M}$ phosphate buffer $(\mathrm{pH} 7)$ and post-fixed in $2 \%$ Osmium tetraoxide (OsO4) $(\mathrm{pH} \mathrm{7)}$. Samples were then taken through an alcohol dehydration series $(15 \%, 25 \%, 40 \%, 50 \%, 70 \%$, and $95 \%$ EtOH). SEM samples were critical point dried, sputter-coated to $20 \mathrm{~nm}$ with gold/paladium, and mounted on aluminum stubs for observation under a Phillips (SEM at 10-15 kV), Karnowsky (1965) and Fischer et al. (2012). Trichomes were counted using Compu Eye, Leaf and Symptom Area soft were according to Bakr (2005).

\section{Statistical Analysis:}

Statistical analysis was conducted using SAS program (1998). The ANOVA test was used to evaluate the significant differences among cultivars, and means were separated using Duncan's multiple range test. Also, correlation coefficient ( $r$ ) was used to determine the relation of different trichomes of tomato leaflet and $T$. absoluta infestation.

\section{RESULTS AND DISCUSSION}

\section{Susceptibility of certain tomato cultivars to $T$. absoluta infestation:}

\section{Early summer plantation:}

Results of seasonal abundance of $T$. absoluta population density on the five tomato cultivars were represented in Table 1 . These results indicated that seasonal abundance was higher than in season 2013 that was recorded in season 2014 with seasonal mean numbers; 5.93 and 5.20 larvae/10 leaflets for the two seasons, respectively.

In season 2013, statistical analysis of variances among different seasonal means of $T$. absoluta population density indicated significant differences $(F=3.2)$, where the 
highest seasonal mean number recorded on Alissa F1cultivar with mean number 8 larvae/10 leaflets, followed by Super Strain B and Indos cultivars with mean numbers, 7.31 and 4.93 larvae/10 leaflets. On the other hand, on GS 12 F1 and Logain (E603 F1) cultivars the lowest mean numbers were recorded (4.76 and 4.66 larvae/10 leaflets, respectively).

In season 2014, statistical analysis of variances among different seasonal means of T. absoluta population density indicated high significant differences $(F=8.43)$, where the highest seasonal mean numbers were recorded for Alissa F1 and Super Strain B cultivar being 7 and 6.45 larvae/10 leaflets, respectively, followed by GS 12 F1 cultivar with mean number of 5.81 larvae/10 leaflets, then Indos cultivar with mean number 4.07 larvae/10 leaflets. While the lowest seasonal mean number was recorded for Logain E603 F1cultivar (2.68 larvae/leaflet).

\section{Summer plantation:}

Results of seasonal abundance of $T$. absoluta population density on the five tomato cultivars were presented in Table 2 . These results indicated that seasonal abundance was higher, in season 2013, than that was recorded in season 2014 with seasonal mean numbers of 3.28 and 3.04 larvae/10 leaflets, respectively.

In season 2013, statistical analysis of variances among different seasonal means of T. absoluta population density indicated moderate significant differences $(F=4.55)$, where the higher seasonal mean numbers were recorded on Super Strain B, Alissa F1, GS 12 F1 and Indos cultivars with mean numbers of population density; 3.67, 3.62, 3.45 and 3.40 larvae/10 leaflets. While the lower seasonal mean number of population density was 2.29 larvae/ 10 leaflets on Logain E603 F1 cultivar.

In season 2014, statistical analysis of variances indicated insignificant differences among different seasonal means of $T$. absoluta population density $(F=2.05)$. The highest seasonal mean numbers were recorded on Alissa F1, Super Strain B and GS 12 F1 cultivars $(3.52,3.24$ and 3.14 larvae/10 leaflets for the three cultivars, respectively). followed by Indos cultivar with mean number of 3.02 larvae/10 leaflets. While the lowest mean number (2.31 larvae/10 leaflets) was recorded on Logain (E603 F1) cultivar.

From the aforementioned results it could be concluded that the most susceptible cultivars for $T$. absoluta infestation were Alissa F1 and Super strain B cultivars with seasonal mean numbers of 5.53 and 5.16 larvae/10 leaflets, followed by both G.S 12 F1and Indos cultivars with seasonal mean numbers of 4.29 and 3.85 larvae/10 leaflets. While Logain (E603 F1) showed highly resistance against $T$. absoluta infestation with seasonal mean number of population density 2.97 larvae/10 leaflets. 
Highest population density of the T. absoluta on tomato were between Mar. Jun and in Sep.-Oct. (Picanco et al. (2000), Ecole et al. (2001), Miranda et al. (2005), Nannini et al. (2011)). And The most Susceptibility varieties to larval attacks of $T$. absoluta were "Doucen, Zahra and Kartier" whereas "CLX" and "Pietro" had lower infestation rates. (Allal et al. 2011). Alisa tomato variety was more susceptible to the T. absoluta infestation than Super strain B (Ata and Megahed 2014). Tomato varieties, Fyrouz and $\mathrm{H} 9780$ were the most susceptible to $T$. absoluta infestation followed by Alissa, Hadir, and Elbasha 1077 (Shawir et al. 2014 ).

\section{Effect of tomato leaflet morphology on $T$. absoluta infestation:}

Tomato leaflet surfaces morphology was scanned by the scanning electronic microscope to detect the relationship among different trichome's type, density, length and width of the five tomato cultivars and T. absoluta infestation. Results in fig. 1 indicated that there are two types of tricomes in both tomato leaflet surfaces in all the five tomato cultivars; one of them is a non glandular type (III) and the other one is a glandular type (VI). This identification is based on Glas et al., (2012).

Statistical analysis of simple correlation among these two types of trichome's density, length and width of five tomato cultivars and $T$. absoluta infestation (Table 3) showed a negative significant relationship $(r=-0.89-p=0.04)$ between the glandular trichome (VI) density (numbers) and T. absoluta infestation. The highest mean number of this trichome type was detected in Logain (E603F1) cultivar (22.6 trichome/ Imm² leaflet), followed by Indos, Super strain B, GS 12 F1 and Alissa F1 with mean numbers of $8,5.4,3.8$ and 3.2 trichomes/ $\mathrm{Imm}^{2}$ leaflet. Also there is a negative relationship among glandular trichome' length and positive relationship to their width. In addition, the length of non glandular trichomes was negatively correlated with $T$. absoluta infestation .

From the above mentioned results it could be suggested that glandular trichome (VI type) might play an important role in tomato cultivar resistance against $T$. absoluta infestation. Obtained results were in agreement with those obtained by Gilardon et al. (2001), Leite et al. (2001) and Glas et al. (2012) who mentioned that in genus Lycopersicon different metabolites and substances are secreted by glandular trichomes of leaves and stems. These substances have evolved to provide the plant with protection against herbivores and pathogens. 
834 SUSCEPTIBILITY OF CERTAIN TOMATO CULTIVARS TO INFESTATION WITH TUTA ABSOLUTA (MEYRICK) (LEPIDOPTERA:GELECHIIDAE) IN RELATION TO LEAFLET TRICHOMES

Table 1. Weekly mean numbers of $T$. absoluta larvae/leaflet on five tomato cultivars throughout early summer season during year, 2013 and 2014 at Qaha farm, Qalyubiya Governorate.

\begin{tabular}{|c|c|c|c|c|c|c|c|c|c|c|}
\hline \multirow{2}{*}{$\begin{array}{c}\text { Sampling } \\
\text { dates }\end{array}$} & \multicolumn{3}{|l|}{ Alissa F1 } & \multicolumn{2}{|c|}{ Indos } & \multicolumn{2}{c|}{$\begin{array}{l}\text { Logain } \\
\text { E603 F1 }\end{array}$} & \multicolumn{2}{c|}{$\begin{array}{c}\text { Super } \\
\text { strain B }\end{array}$} & \multicolumn{2}{c|}{ G.S 12 F1 } \\
\cline { 2 - 13 } & 2013 & 2014 & 2013 & 2014 & 2013 & 2014 & 2013 & 2014 & 2013 & 2014 \\
\hline 5 March & 0.00 & 4.67 & 1.00 & 1.33 & 0.00 & 0.67 & 0.33 & 3.00 & 2.67 & 2.00 \\
\hline $12 / 03$ & 9.67 & 7.67 & 4.00 & 3.67 & 1.33 & 1.67 & 8.67 & 7.00 & 4.67 & 5.33 \\
\hline $19 / 03$ & 3.00 & 4.67 & 18.3 & 8.33 & 9.00 & 7.00 & 11.7 & 6.67 & 11.67 & 10.67 \\
\hline $26 / 03$ & 7.33 & 7.33 & 5.33 & 9.33 & 4.33 & 7.67 & 7.33 & 5.33 & 0.67 & 13.00 \\
\hline $02 / 04$ & 5.67 & 9.00 & 1.33 & 7.67 & 1.67 & 4.67 & 7.67 & 18.33 & 1.67 & 10.67 \\
\hline $09 / 04$ & 3.00 & 6.00 & 2.33 & 4.33 & 2.00 & 3.00 & 5.00 & 14.00 & 1.33 & 6.67 \\
\hline $16 / 04$ & 3.67 & 6.67 & 3.00 & 6.67 & 5.00 & 4.00 & 6.33 & 5.00 & 3.00 & 7.67 \\
\hline $23 / 04$ & 8.00 & 12.3 & 4.33 & 3.00 & 3.67 & 2.00 & 6.67 & 7.00 & 5.33 & 6.67 \\
\hline $30 / 04$ & 3.33 & 7.00 & 1.33 & 2.67 & 0.67 & 2.00 & 4.67 & 4.33 & 2.00 & 3.33 \\
\hline $07 / 05$ & 11.67 & 8.00 & 5.67 & 3.67 & 6.67 & 2.00 & 7.00 & 5.00 & 9.67 & 4.67 \\
\hline $14 / 05$ & 25.33 & 8.00 & 4.33 & 2.67 & 6.33 & 0.67 & 8.67 & 7.00 & 9.67 & 5.33 \\
\hline $21 / 05$ & 21.00 & 10.3 & 6.67 & 3.33 & 10.67 & 1.33 & 17.3 & 5.00 & 10.33 & 4.00 \\
\hline $28 / 05$ & 9.33 & 4.33 & 6.00 & 0.33 & 10.33 & 0.00 & 7.67 & 2.00 & 4.00 & 1.00 \\
\hline $04 / 06$ & 1.00 & 2.00 & 5.33 & 0.00 & 3.67 & 0.00 & 3.33 & 0.67 & 0.00 & 0.33 \\
\hline Mean & $8.0 \mathrm{a}$ & $7.0 \mathrm{a}$ & $4.9 \mathrm{ab}$ & $4.1 \mathrm{bc}$ & $4.7 \mathrm{c}$ & $2.7 \mathrm{c}$ & $7.3 \mathrm{ab}$ & $6.4 \mathrm{a}$ & $4.8 \mathrm{c}$ & $5.8 \mathrm{ab}$ \\
\hline
\end{tabular}

$F$ value for season $2013=3.20 * \quad L S D=2.49 \quad F$ value for season $2014=8.43^{* * *} \quad L S D=1.79$

Table 2. Weekly mean numbers of $T$. absoluta Larvae/leaflet on five tomato cultivars throughout summer season during year 2013 and 2014 at Qaha farm, Qalyubiya Governorate.

\begin{tabular}{|c|c|c|c|c|c|c|c|c|c|c|}
\hline \multirow{2}{*}{$\begin{array}{c}\text { Sampling } \\
\text { dates }\end{array}$} & \multicolumn{2}{|c|}{ Alissa F1 } & \multicolumn{2}{|c|}{ Indos } & \multicolumn{2}{c|}{$\begin{array}{c}\text { Logain } \\
\text { E603 F1 }\end{array}$} & \multicolumn{2}{c|}{$\begin{array}{c}\text { Super } \\
\text { strain B }\end{array}$} & \multicolumn{2}{c|}{ G.S 12 F1 } \\
\cline { 2 - 13 } & 2013 & 2014 & 2013 & 2014 & 2013 & 2014 & 2013 & 2014 & 2013 & 2014 \\
\hline 02 July & 4.33 & 1.33 & 3.33 & 0.33 & 1.00 & 0.00 & 4.67 & 0.33 & 2.00 & 1.33 \\
\hline $09 / 07$ & 5.33 & 1.67 & 2.67 & 1.33 & 1.33 & 0.00 & 3.67 & 2.00 & 1.67 & 2.67 \\
\hline $16 / 07$ & 3.67 & 2.67 & 4.67 & 2.67 & 2.33 & 0.00 & 3.00 & 3.00 & 4.33 & 2.33 \\
\hline $23 / 07$ & 4.00 & 3.67 & 6.67 & 4.33 & 4.33 & 0.00 & 3.33 & 4.33 & 6.00 & 3.33 \\
\hline $30 / 07$ & 4.33 & 5.67 & 5.67 & 2.67 & 2.33 & 2.33 & 3.33 & 2.33 & 5.33 & 5.67 \\
\hline $06 / 08$ & 3.00 & 5.00 & 2.67 & 2.67 & 2.67 & 5.00 & 5.00 & 2.67 & 4.00 & 5.00 \\
\hline $13 / 08$ & 3.33 & 7.00 & 3.67 & 2.33 & 4.00 & 6.33 & 4.67 & 2.33 & 6.33 & 3.00 \\
\hline $20 / 08$ & 3.33 & 5.67 & 3.67 & 5.67 & 5.00 & 5.67 & 3.33 & 5.33 & 5.33 & 3.33 \\
\hline $27 / 08$ & 4.00 & 3.67 & 3.00 & 5.00 & 4.33 & 3.33 & 3.33 & 5.00 & 3.00 & 3.00 \\
\hline $03 / 09$ & 2.33 & 2.00 & 1.33 & 3.67 & 3.00 & 1.67 & 2.67 & 3.67 & 1.33 & 2.67 \\
\hline $10 / 09$ & 4.67 & 2.67 & 1.67 & 4.67 & 1.33 & 2.67 & 3.33 & 4.67 & 2.33 & 2.67 \\
\hline $17 / 09$ & 3.67 & 1.33 & 1.67 & 4.33 & 0.33 & 1.00 & 3.33 & 4.67 & 0.67 & 1.33 \\
\hline $24 / 09$ & 4.00 & 5.00 & 4.00 & 2.00 & 0.00 & 2.33 & 3.67 & 3.33 & 4.33 & 5.00 \\
\hline $01 / 10$ & 0.67 & 2.00 & 3.00 & 0.67 & 0.00 & 2.00 & 4.00 & 1.67 & 1.67 & 2.67 \\
\hline Mean & $3.62 \mathrm{a}$ & $3.5 \mathrm{a}$ & $3.4 \mathrm{a}$ & $3.0 \mathrm{ab}$ & $2.29 \mathrm{~b}$ & $2.3 \mathrm{~b}$ & $3.7 \mathrm{a}$ & $3.2 \mathrm{a}$ & $3.45 \mathrm{a}$ & $3.14 \mathrm{a}$ \\
\hline
\end{tabular}


Table 3. Density and Dimensions of trichomes of five tomato cultivars in relation to mean numbers of $T$. absoluta population density.

\begin{tabular}{|c|c|c|c|c|c|c|}
\hline \multirow{3}{*}{$\begin{array}{l}\text { Tomato } \\
\text { cultivars }\end{array}$} & \multicolumn{5}{|c|}{ Trichomes } & \multirow{3}{*}{$\begin{array}{c}\text { Larvae/ } \\
\text { leaflet }\end{array}$} \\
\hline & \multicolumn{3}{|c|}{ Glandular } & \multicolumn{2}{|c|}{ Non glandular } & \\
\hline & $\begin{array}{c}\text { Mean } \\
\text { number }\end{array}$ & Length $(\mu \mathrm{m})$ & Width $(\mu \mathrm{m})$ & $\begin{array}{c}\text { Mean } \\
\text { number }\end{array}$ & Length $(\mu \mathrm{m})$ & \\
\hline Alissa F1 & $3.2 \mathrm{~d}$ & $106.50 \mathrm{ab}$ & $55.06 \mathrm{a}$ & 169 & $163.97 \mathrm{~d}$ & 7 \\
\hline Indos & $8 \mathrm{~b}$ & $114.55 a b$ & $53.18 \mathrm{a}$ & 177 & $172.44 \mathrm{~d}$ & 4.07 \\
\hline E603 F1 (Logain) & $22.6 \mathrm{a}$ & $124.71 \mathrm{a}$ & $52.95 \mathrm{a}$ & 210 & $270.54 \mathrm{a}$ & 2.62 \\
\hline Super strain B & $5.4 \mathrm{c}$ & $109.59 \mathrm{ab}$ & 58.04 a & 245 & $199.25 \mathrm{C}$ & 6.45 \\
\hline G.S 12 F1 & $3.8 \mathrm{~cd}$ & $119.82 a b$ & $55.48 \mathrm{a}$ & 233 & $244.3 b$ & 5.81 \\
\hline Correlation value & -0.894 & -0.815 & 0.774 & 0.087 & -0.567 & - \\
\hline$P$ value & 0.041 & 0.093 & 0.125 & 0.889 & 0.318 & - \\
\hline
\end{tabular}

Glandular: L.S.D.( Mean number $=2.00$ Length $=17.83$ Width $=11.34$ )

Non glandular: L.S.D.( Length $=15.69)$ 


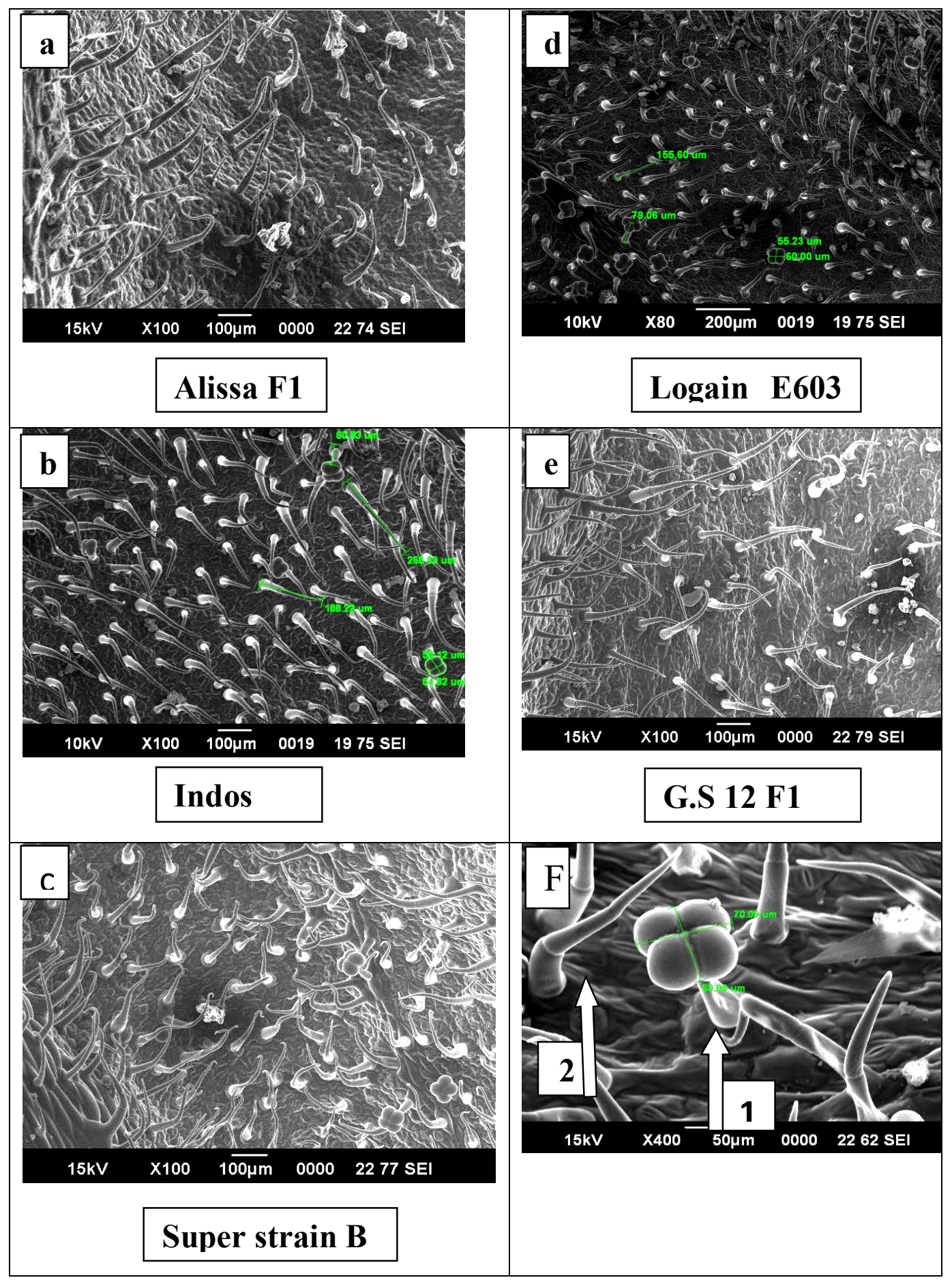

Fig. 1. Scanning electron microscopic images of five tomato cultivars showing different trichome types a Alissa F1; b Indos; c Super strain B; d Logain (E603) ; e G.S 12 F1; f, 1 Glandular trichomes (thick and short glandular trichomes of two stalk cells and a head made up of secretory cell), 2 non-glandular trichomes composed of one basal and thick cell with a leaning cell in the tip. 


\section{REFERENCES}

1. Allal, B. L.; M. Bellatreche; F. Bounaceur; G. Tail and H. Mostefaoui. 2011. Distribution of the infestations and larval generations of the tomato moth on five tomato varieties in greenhouse: is there a varietal resistance? [French] Les Cochenilles: ravageur principal ou secondaire. 9eme Conference Internationale sur les Ravageurs en Agriculture, SupAgro, Montpellier, France, 25-27 Octobre 2011 335.

2. Anonymous. 2013. Agricultural Statistics Bulletin. Central Administration of Economic. Ministry of Agriculture, Egypt, 170 pp.

3. Ata, T. E. and M. M. M. Megahed. 2014. Population Density of Tomato Leafminer Tuta absoluta (Meyrick) (Lepidoptera: Gelechiidae) under Protected Cultivation in Egypt. Middle East J. Agric.Res. 3(4): 1242-1247.

4. Bakr, E. M. 2005. A new software for measuring leaf area, and area damaged by Tetranychus urticae Koch. J. App. Entomol. 129 (3), 173-175.

5. Behnke, H. D. 1984. Plant trichomes-structure and ultra structure: general terminology, taxonomic applications, and aspects of trichome-bacterial interaction in leaf tips of Dioscorea. In: Rodriguz E, Healey PL, Mehta I, eds. Biology and chemistry of plant trichomes. New York: Plenum Press, 1-21.

6. Ecole, C. C.; M. C. Picanço; R. N. C. Guedes and S. H. Brommonschenkel. 2001. Effect of cropping season and possible compounds involved in the resistance of Lycopersicon hirsutum f. typicum to Tuta absoluta (Meyrick) (Lep., Gelechiidae). J. App. Entomol. 125 (4): 193-200.

7. Eigenbrode, S. D. and J. T. Trumble, 1993. Antibiosis to beet armyworm (Spodoptera exigua) in Lycopersicon accessions. Horticultura Brasileira, 28, 932934.

8. Fischer, E. R.; B. T. Hansen; V. Nair; F. H. Hoyt and D. W. Dorward. 2012. Scanning Electron Microscopy. Curr Protoc Microbiol, 76p.

9. EPPO, 2005. Datasheets on quarantine pests: Tuta absoluta. EPPO Bulletin 35:434-435.

10.FAOSTAT, 2014. Egypt Country Profile:http:// faostat.fao.org/ Country Profiles/Country_Profile/ Direct.aspx?lang=en\&area =59 visited in March 2014.

11. Gilardon, E.; M. Pocovi; C. Hernandez; and A. Olsen. 2001. Role of tomato leaf glandular trichomes in oviposition of Tuta absoluta. [Portuguese] Pesquisa Agropecuaria Brasileira, 36(3):585-588. 
12. Glas J. J.; B. C. J. Schimmel; J. M. Alba; B. R. Escobar and R. C. Schuurink. 2012. Engineering of Resistance to Herbivores. Int J Mol Sci13:17077-17103.

13. Karnowsky, M. J. 1965. A formaldehyde-glutaraldehyde fixative of high osmolarity for use in electron microscopy. J. Cell Biol. 27, 137A.

14. Kennedy, G. G. and M. B. Dimock. 1983. 2-tridecanone: a natural toxicant in the wild tomato responsible for insect resistance. Proceeding of Fifth International Congress on Pesticide Chemistry, Kyoto, Japan 29 August- 4 September 1982.

15. Khanjani, M. 2013. Vegetable pest in Iran, 5nd Edition, Bu-Ali Sina University Press Center, Iran, pp. 467.

16. Leite, G. L. D.; M. C. Picanço; R. N. C. Guedes and J.C. Zanuncio. 2001. Role of plant age in the resistance of Lycopersicon hirsutum f. glabratum to the tomato leaf miner Tuta absoluta (Lepidoptera: Gelechiidae). Sci. Hort., 89, 103-113.

17. Miranda, M. M. M.; M. C. Picanço; J. C. Zanuncio; L. Bacci and E. M. Silva. 2005. Impact of integrated pest management on the population of leafminers, fruit borers, and natural enemies in tomato. Ciencia Rural, 35 (1): 204-208.

18. Nannini, M.; F. Atzori; F. Foddi; R. Pisci and F. Sanna. 2011. A survey of Tuta absoluta (Meyrick) (Lepidoptera: Gelechiidae) outbreaks in tomato greenhouses in Southern Sardinia (Italy). Acta Hort., 917: 39-46.

19. Picanço, M. C. 2000. Manejo integrado de pragas de hortaliças. In Zamboloml. (Ed). Manejo integrado de doenças, pragas e ervas daninhas. Viçosa: UFV. 8: 275324.

20. Roditakis, E. and N. Seraphides. 2011. The current status of Tuta absoluta in Greece and Cyprus, in EPPO/IOBC/FAO/NEPPO Joint International Symposium on Management of Tuta absoluta, Agadir, Morocco, 16-18 November, p. 20

21. SAS Institute.1988. SAS user's guide: statistics. SAS Institute, Cary, N.C.

22. Shawir, M. S.; A. El-bakary; S. A. M. Abdelgaleil and G. R. M. Ramadan. 2014. Susceptibility of five tomato varieties to Tuta absoluta infestation in insecticide treated fields. Alexandria Science Exchange Journal, 35: p249

23. Simmons, A.T.; G. M. Gurr; D. Mcgrath; H. I. Nicol and P. M. Martin. 2003. Trichome of Lycopersicon and their effect on Myzus persicae (Homoptera: Aphididae). Australian J Entomol., 42: 373- 378.

24. Temerak, S. A. 2011. Status of the tomato borer, Tuta absoluta (Meyrick) in Egypt. EPPO/IOBC/FAO/NEEPPO joint international Symposium on management of Tuta absoluta (tomato borer), Agadir, Morocoo, November, 2011. 
25.Torres, J. B.; C. A. Faria; W. S. Evangelista and D. Pratissoli. 2001. Within-plant distribution of the leaf miner Tuta absoluta (Meyrick) immatures in processing tomatoes, with notes on plant phenology. International J Pest Management, 47(3): 173-178.

26. Werker, E., D. L. Hallahan and J. C. Gray. 2000. Trichome diversity and development. In Plant Trichomes; Eds., Academic Press: New York, NY, USA, p. 1.

27. Weston, P. A.; D. A. Johnson; H. T. Burton and J. C. Snyder. 1989. Trichome secretion composition, trichome densities, and spider mites resistance of ten accessions of Lycopersicon hirsutum. J Amer. Soc. Hort. Sci., 114: 492-498.

28. Williams, W. G.; G. G. Kennedy; R. T. Yamamoto; J. D. Thacker and J. Bordner. 1980. Tridecanone a naturally occurring insecticide from the wild tomato Lycopersicon hirsutum f. glabratum. Science, 207: 888-889. 
840 SUSCEPTIBILITY OF CERTAIN TOMATO CULTIVARS TO INFESTATION WITH TUTA ABSOLUTA (MEYRICK) (LEPIDOPTERA:GELECHIIDAE) IN RELATION TO LEAFLET TRICHOMES

\title{
حساسية بعض أصناف الطماطم للاصابة بحشرة التوتا ابسليوتا

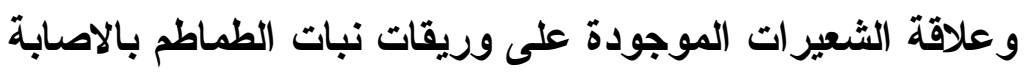

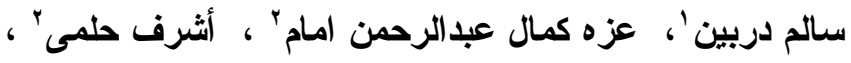 \\ سامى سيد البدوى'، سعد موسى' \\ ا ـ ـعهُ بحوث وقاية النباتات - مركز البحوث الزراعية - الدقى- الجبزة - مصر. \\ r ـ قسم وقاية النبات - كلبة الزراعة - جامعة عين شمس - مصر .
}

تعتبر حشرة حافرة أوراق الطماطم Tuta absoluta من أهم أفات الطماطم على مسنوى

العالم وقد وجد أن أصناف الطماطم تلعب دور ا هاما فى مكافحة هذه الافة .تم دراسة حساسية خمسة اهنة أصناف طماطم للاصابة بهذه الافة وعلاقة هذه الحساسية بالشعيرات الموجودة على وريقة الطماطم • وقد تم زر اعة خمسة أصناف اليسا F1 ، سوبر استرين B ، جى اس Y I F1 ، لوجين (E603)

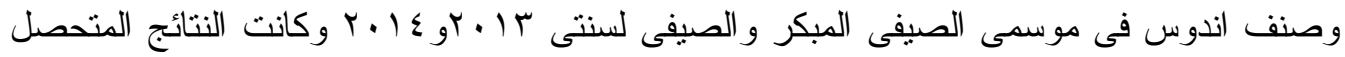

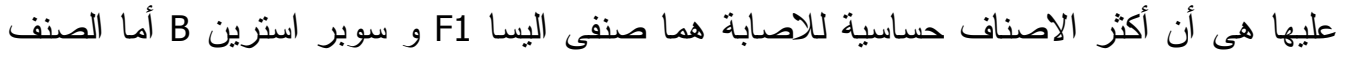
لوجين كان أقل الاصناف حساسية للاصابة كما وجد نوعين من الثعيرات على وريقات نبات الطماطم (شعيرات غدية وشعيرات عاديه) ومن الدراسة وجد أن عدد وطول الثعيرات الغدية الغنية ارتبطت ارتباط سالب عالى المعنوية مع أعداد الحشرة وكذللك ارتبطت طول الثعرة العاديه ارتباط سالب معنوى مع اعداد الحشرة . أبطان 